\author{
Marcin GĄSIOR ${ }^{1}$ \\ Lukasz SKOWRON ${ }^{2}$ \\ Stanisław SKOWRON ${ }^{3}$
}

\title{
UKRAINIAN LABOUR MARKET FROM THE PERSPECTIVE OF POLES - STEREOTYPES OR NEGATIVE EXPERIENCES?
}

\begin{abstract}
Short- and long-term migration for economic purposes became, within the last decade, a typical and inseparable part of the Polish labour market. The most frequently chosen destinations include, in most cases, Western European countries like Norway, while the United States are chosen less frequently. What is important, the eastern neighbours of Poland almost never become the migration destination. A question can thus appear about the reason for the above mentioned aversion to take up employment in this part of the continent. Is it caused solely by factors of economic nature, or does the source lie also in the area of the usually quite negative image of Eastern European countries? The purpose of this article is to attempt to assess, using the example of the Ukrainian market, how the Polish employees perceive the eastern labour markets and, moreover, to verify, to what extent these perceptions are a derivative of the functioning stereotypes, or a consequence of own professional experience. Obtained results show that the aforementioned market is perceived in a clearly negative way, especially in the area concerning work, its conditions, and professional opportunities. Nonetheless, it should be pointed out that in fact some stereotypes do exist - employees who had actually visited Ukraine, had the tendency to evaluate the local labour market slightly better than those who had never been there.
\end{abstract}

Keywords: Ukraine, labour market, polish employees' opinions

\section{INTRODUCTION}

Migration for economic purposes, both temporary and long-term, has become a permanent aspect of the Polish labour market. According to the estimation of the Central Statistical Office, at the end of 2013, 2 million 196 thousand Poles stayed outside the borders of Poland ${ }^{4}$, which constitutes almost $6 \%$ of the population. It should also be emphasized that, in recent years, this amount has been growing, and more than $75 \%$ of temporary migrants remain beyond the country for at least 12 months. It can thus be presumed that work in the country becomes less attractive prospect, both for structural reasons, reasons related to the labour market, as well as due to some social and cultural conditions.

\footnotetext{
${ }^{1}$ Marcin Gąsior, PhD, Eng., Faculty of Management, Lublin University of Technology, Lublin, ul. Nadbystrzycka 38d, e-mail: m.gasior@ pollub.pl (corresponding author)

${ }^{2}$ Łukasz Skowron, PhD, Eng, Faculty of Management, Lublin University of Technology, Lublin, ul. Nadbystrzycka 38d, e-mail: lukasz.m.skowron@gmail.com

${ }^{3}$ Stanisław Skowron, Prof. DSc, PhD, Eng., Faculty of Management, Lublin University of Technology, Lublin, ul. Nadbystrzycka 38d, e-mail: s.skowron@pollub.pl.

${ }^{4}$ Informacja o rozmiarach i kierunkach emigracji z Polski w latach 2004-2013, GUS, Warszawa 2014.
} 
The literature indicates various reasons for this situation. In the area of labour market, the following processes can be specified: ${ }^{5}$ growth in the area of temporary work (employment for definite time), low level of net wages, low level of minimum wage, and a significant growth in the number of people belonging to the category of the so-called working poor. Also important are the fiscal and social care solutions, which are more beneficial in other countries ${ }^{6}$, as well as, naturally, the difficulties with finding employment observable in Poland ${ }^{7}$.

As it was indicated by the statistics, the dominant emigration destinations include the European Union countries ${ }^{8}$. 1.789 million employees found employment therein, which constitutes more than $81 \%$ of the leaving population. Norway is the most important labour market among the countries from outside the European Union. It is worth mentioning that there are no former Eastern Bloc countries on the list, including Baltic republics.

Reluctance to emigrate in search of work to the countries of the Eastern Europe among others to Ukraine, being the subject of interest of this article - should be primarily ascribed to the conflict with the abovementioned basic drivers, encouraging people to seek work abroad. The most important discouraging factor is most likely the low - from the point of view of a Polish employee - wage level. It is also worth emphasizing that the system solutions applied there, as well as the mentality of the employers, do not support personal initiative of the employees and do not build the sense of job security. The willingness to invest in trainings and development of relations between employees and employer is also missing, which ultimately is a strongly discouraging factor affecting the employees ${ }^{9}$. Finally, one should note that people prefer countries with higher standard of living, higher economic growth and higher gross domestic product as the destination of their migration movement.

At the same time, it should be emphasized that the Ukrainian labour market, both on the part of employees, as well as the employers, struggles with a number of problems of legal, financial and organizational nature, which directly translate into how it is perceived and assessed, both locally and on the international arena. These problems may include, among others, corruption, constituting a great burden for the entities ${ }^{10}$, and organized crime, in particular crime of economic nature ${ }^{11}$, or the tendency to run business operations

\footnotetext{
${ }^{5}$ G. Firlit-Fesnak, Polityka spoteczna w Polsce wobec wspótczesnych procesów migracyjnych. Próba diagnozy i rekomendacje, „Studia Migracyjne - Przegląd Polonijny” $39 / 149$ (2013), s. 22.

${ }^{6}$ J. Adamiak et al., Wybrane aspekty regulacji podatkowych we wskazanych krajach Europy jako potencjalny czynnik wptywający na emigracje, „Zeszyty Naukowe Uniwersytetu Szczecińskiego” 818, „Finanse, Rynki Finansowe, Ubezpieczenia" 2014/68.

${ }^{7}$ M. Pasternak-Malicka, Przyczyny i skutki migracji zagranicznych mtodych Polaków, „Zeszyty Naukowe Uniwersytetu Szczecińskiego” 787, „Współczesne Problemy Ekonomiczne. Globalizacja. Liberalizacja. Etyka” 2013/7.

${ }^{8}$ See e.g. Informacja o rozmiarach i kierunkach emigracji...

9 O. Machtakova, Employee motivation in Ukrainian enterprises, "Вісник соціально-економічних досліджень" 3/46 (2012).

${ }^{10}$ M. Hanson, Transition in Ukraine, Report Number 065 Escew 06 E, NATO Parliamentary Assembly, Brussels 2006.

${ }^{11}$ See J. Finckenauer, J. Shrock, The Prediction and Control of Organized Crime: The Experience of Post-Soviet Ukraine, Transaction Publishers, Edison, New Jersey 2003.
} 
without registration and informal employment, as methods to avoid contact with the tax administration, which is not always fair ${ }^{12}$.

There are no studies on the scale of emigration for financial reasons to this country, both long-term and short-term. The subject literature, when discussing the issues of migration movements between Poland and Ukraine, focuses usually on Ukrainian employees, coming to Poland and returning to Ukraine, ignoring - probably for justified reasons - the Poles $^{13}$.

A question can thus appear of how this market would be perceived in the event of offering a wage level attractive for the Polish employee. Is the observed unwillingness to emigrate there only caused by financial factors, or is it a derivative of other variables?

The purpose of this article is the assessment of how the Polish employees perceive the Ukrainian labour market, both in its financial aspects, as well as in non-financial areas related to the image and social aspects, and therefore to answer three research questions: what is the perception of (1) image and culture-related factors, (2) professional and work environment, and (3) social and personal areas of local labour market, and how that perception correlates with the fact, that employee had or had not previously visited that country.

At the same time, an attempt was made to answer the question of: to what extent this perception is a reflection of the objective situation on the discussed market, and to what degree it is the result of the prevailing prejudices and the functioning stereotypes. Additionally, the hypothesis that employees' evaluation of consecutive areas improve in groups of people who visited Ukraine once and more than one time had been tested.

\section{THE ADOPTED RESEARCH METHODOLOGY}

The research on the perception of the Ukrainian market became a part of a greater research project, the goal of which was to assess the attractiveness and potential destinations, as well as perspectives of cooperation between the border areas of Poland and Ukraine - from the point of view of employees, employers and social dialogue institutions. The part devoted to opinions of employees contains data obtained by way of surveys, carried out by means of a questionnaire covering 92 variables, concerning both the opinion of the surveyed persons with regard to the considered market itself, their susceptibility to take up employment, as well as their expectations and experience, both these of employment nature, as well as others - educational, or tourist ones. At the same time, it should be emphasized that, due to the fact that this market is demonstrably hardly encouraging in terms of economic incentives, the study covered also the potentially important macro-environment factors, going beyond the classic models that explain migration movements. As shown by research, these models, based only on the existence of appropriate disproportions between the achieved, and the potential possible incomes ${ }^{14}$, do not

\footnotetext{
${ }^{12}$ P. Rodgers, C. Williams, J. Round, Workplace crime and the informal economy in Ukraine: Employee and employer perspectives, "International Journal of Social Economics" 35/9 (2008).

${ }^{13}$ K. Iglicka, K. Gmaj, Circular Migration Patterns between Ukraine and Poland, [in:] A. Triandafyllidou, Circular Migration Between Europe and Its Neighbourhood: Choice Or Necessity?, Oxford University Press, Oxford 2013, s. 166.

${ }^{14}$ See e.g. A. Czarnecki, Atrakcyjność rynków pracy matych miast w Polsce (dla ludności miejscowej i dojeżdżających). ,Studia Ekonomiczne/Uniwersytet Ekonomiczny w Katowicach” 144/1 (2013).
} 
explain in a complex manner the susceptibility of employees to search for employment outside the place of residence, as well as to possibly return ${ }^{15}$.

Perceiving the Ukrainian labour market by Polish employees was assessed in three functional areas. The first one concerned the image- and culture-related aspects and covered such variables, as observance of legal regulations and public order, personal safety of citizens, legal protection on the part of the state, attitude of the community towards foreigners, access to information, situation of the economy, and quality of the public administration's operation. The second examined assessment area was the set of socio-economic variables, taking into account efficiency of the traffic and transport system, ease in communication and ease in establishing personal contacts, possibilities of spending free time, standard of living, freedom of belief and freedom of speech, living costs, as well as access to Polish-language press and television, and Internet access. The third area focused around employment and its conditions, and included wage level, compliance with regulations of the labour law and occupational health and safety (OHS), stability of employment, possibility to find employment, protection of an employee on the part of the state, career opportunities, honesty of the employers, as well as atmosphere in the work environment. The respondents were also asked to make a general evaluation of the Ukrainian labour market. All variables were subjected to measurement using ten-step scales, low values of which represented negative evaluation, high values - positive evaluation. The research tool was subject to validation, and tested during the pilot audit carried out on a small group of respondents.

The research sample was selected in a purposeful manner ${ }^{16}$ from among the inhabitants of the Lubelskie Voivodeship. Such a method of sample selection resulted from the need to reach and recruit a fraction of people, who had an experience with contacts with Ukraine, both of employment nature, as well as other nature, for example tourist contacts. The research had been conducted in 2013 - therefore it should be noted that it evaluates the situation before the unrests that started in February 2014.

3129 respondents took part in the discussed survey, including $1640(52.4 \%)$ women and $1440(46 \%)$ men. The remaining group (1.6\% of the sample) did not indicate their gender. The respondents included 892 persons in the age of 18 to 25 years, 744 persons of 26 to 35 years of age, 1053 persons aged from 36 to 55 years, and 271 people above 56 years of age. 169 respondents did not answer the question about their age.

The surveyed group included persons representing subsequent possible levels of education, as well as various professional statuses - persons working on a full-time job, as well as students, unemployed persons or persons running their own business operations. From among all persons covered by the research, 1394 (44.55\% of the sample) declared at least one trip to Ukraine, a vast extent of which were tourist trips, and the remaining part of which was business trips, commercial trips and trips related to participation in training courses. At this point, it should be pointed out that tourist trips were dominant among persons who have visited Ukraine up to three times, whereas the persons visiting

\footnotetext{
15 See O. Verkhohlyad, G.N. McLean, Applying organizational commitment and human capital theories to emigration research, "European Journal of Training and Development" 36/2-3 (2012), or D.S. Massey, J. Arango, G. Hugo, A. Kouaouci, A. Pellegrino, Worlds in Motion: Understanding International Migration at the End of the Millennium. Oxford University Press, Oxford 1999.

${ }^{16}$ G.A. Churchill, Badania marketingowe. Podstawy metodologiczne. Wydawnictwo Naukowe PWN, Warszawa 2002, s. 500
} 
this country more often, declared conducting business and commercial activities as the basic goals of the visits, as well as participation in or conducting trainings.

For further discussion, an assumption has been adopted that a situation, in which the persons who have visited Ukraine evaluate the given issues better than the persons who have never been in this country, proves the functioning of a specific stereotype, which - in the course of the visit - was verified.

\section{PERCEPTION OF THE UKRAINIAN LABOUR MARKET}

The first analysed area includes the opinions with regard to the image and culturerelated aspects of Ukraine and the Ukrainian labour market (graph 1).

Graph 1. Perception of the Ukrainian market - the image and culture-related aspects

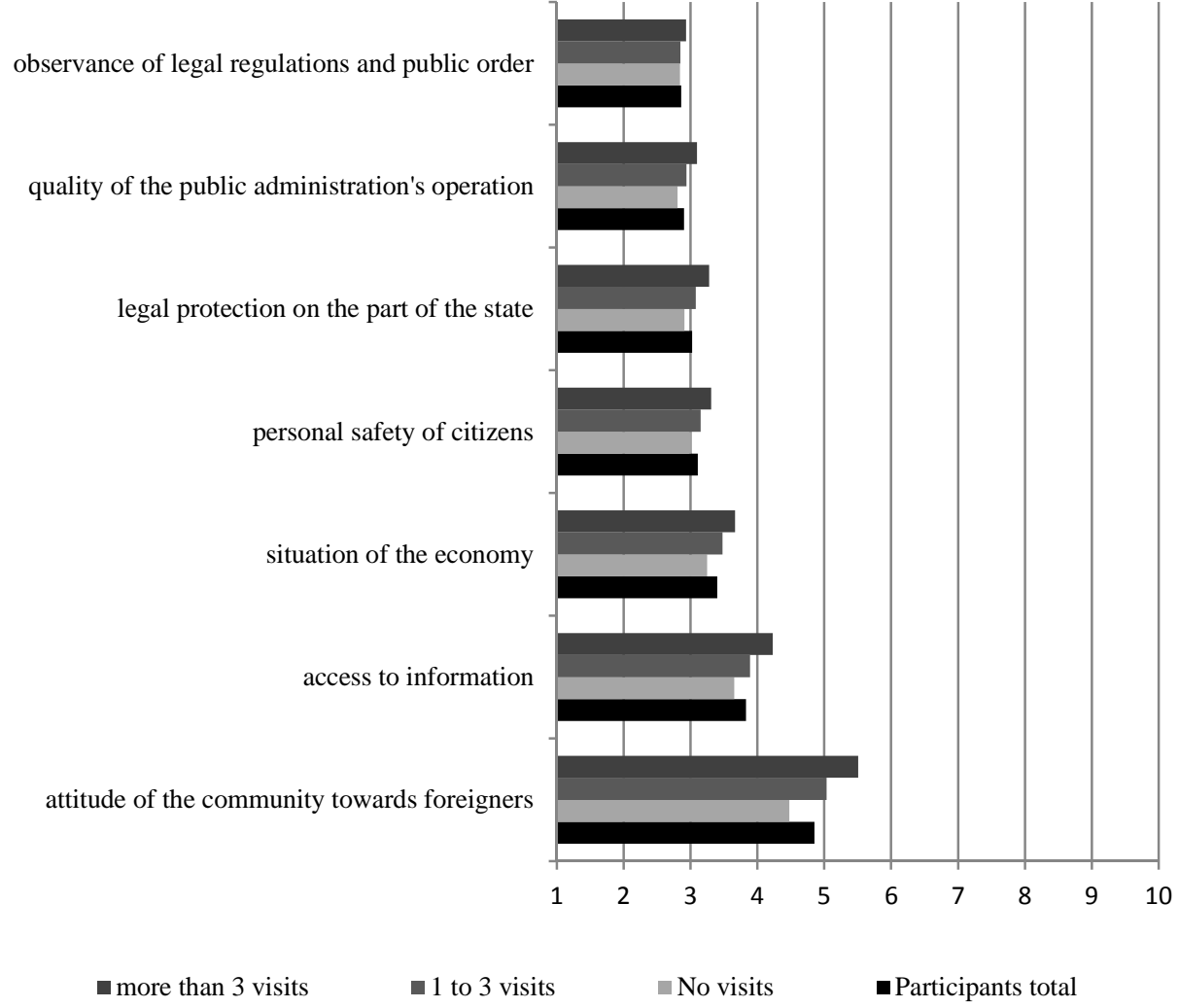

Source: prepared by the author.

The most important conclusion arising from the acquired empirical material is an extremely low assessment of all aspects subject to analysis - as it can be seen, practically none of the studied areas obtained the average rating higher than 5.0. A certain exception is the attitude of the local community towards foreigners, in the case of which the average 
rating reached the value of 4.86 and is significantly dependent on the fact of visiting Ukraine - the persons, who have never visited this country, assessed this attitude significantly lower (4.48) than the persons, who have visited between one and three times (5.03) and more often (5.51). Lower ratings were given to access to information (3.83), situation of the Ukrainian economy (3.40), personal safety (3.11), and legal protection of citizens (3.03), although in all these factors an insignificant increase in their evaluations can also be seen by groups, which have visited Ukraine. The lowest ratings were given to quality of the public administration's operation (2.91) and observance of law and order (2.86).

At the same time, it should be emphasized that, in most of the surveyed aspects, the presented negative evaluation seems to be, to some extent, a derivative of the popular stereotype. The conducted survey (due to the nature of the adopted scales, the U MannWhitney's test) demonstrated the statistically significant $(\mathrm{p}<0.05)$ differences in average ratings between a group of people, who have never visited Ukraine, and a group of people, who have visited this country at least once, for all the presented variables, except for observance of law and order $(p=0.93)$ and quality of the public administration's operation $(\mathrm{p}=0.13)$.

Graph 2. Perception of the Ukrainian market - professional aspects

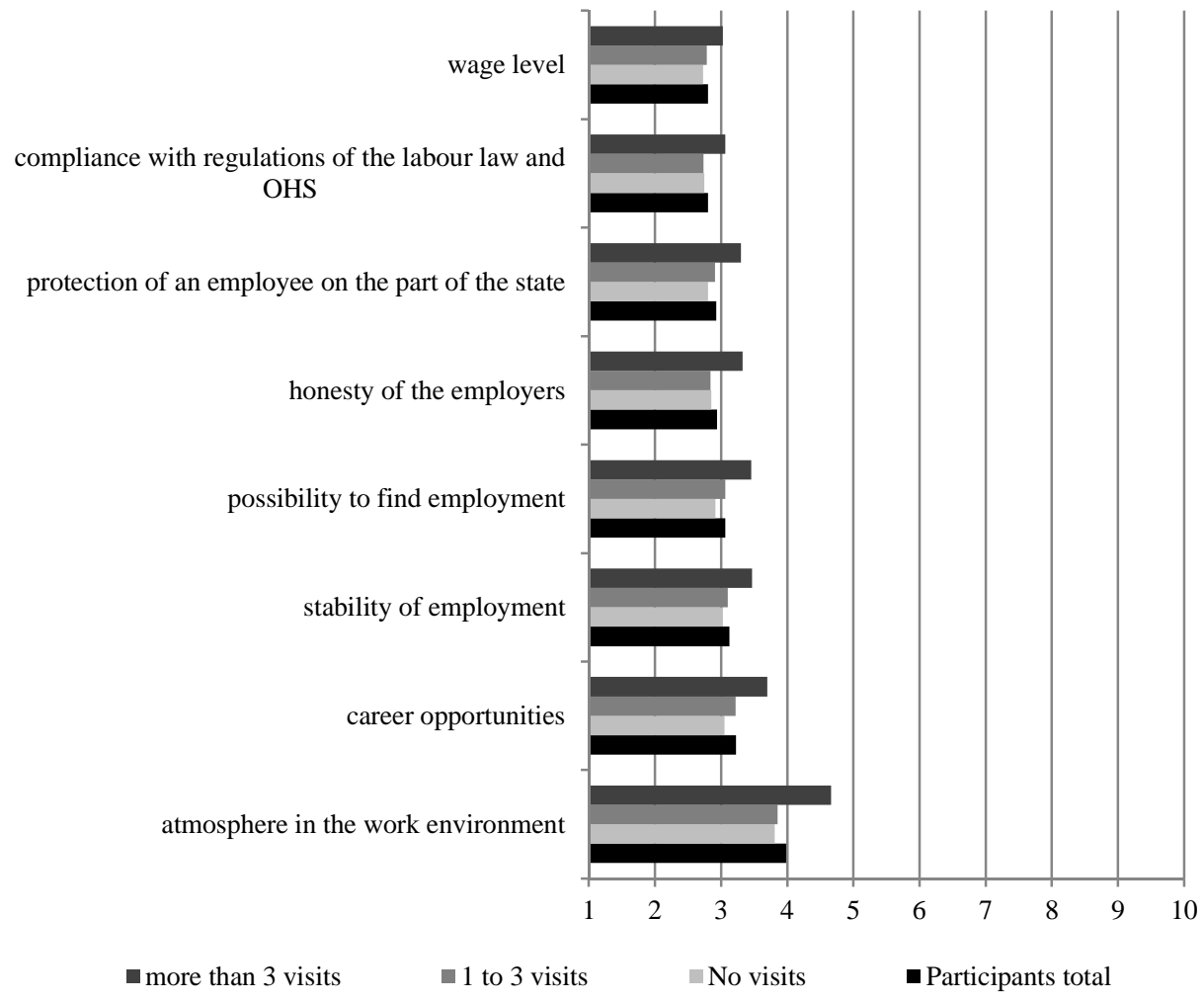

Source: prepared by the author. 
Extremely negative evaluations were also shared by the second of the examined areas, concerning work in Ukraine and its conditions (graph 2 - professional aspects). In this case, again, none of the average ratings exceeded the value of 5.0, and for half of the examined variables, the average rating was below 3.0. Considering the abovementioned significant meaning of the economic factors and the factors related to work conditions, these results seem to explain the reluctance of Polish employees towards the local labour market to a significant extent.

In the discussed area, the highest ratings were given to atmosphere in the work environment (average rating in the whole surveyed group was 3.98), slightly lower - career opportunities (3.22) and stability of employment (3.13). The lowest obtained ratings were for wage level (2.80) and compliance with the labour law (also 2.80).

Comparison of average ratings, calculated separately for the group of people, who have never visited Ukraine and people, who have visited this country at least once, again leads to the conclusion of the existence of statistically significant differences between them. They take place for all analysed variables, except for compliance with labour law $(p=0.44)$ and honesty of the employers $(p=0.25)$.

Graph 3. Perception of the Ukrainian market - socio-personal aspects

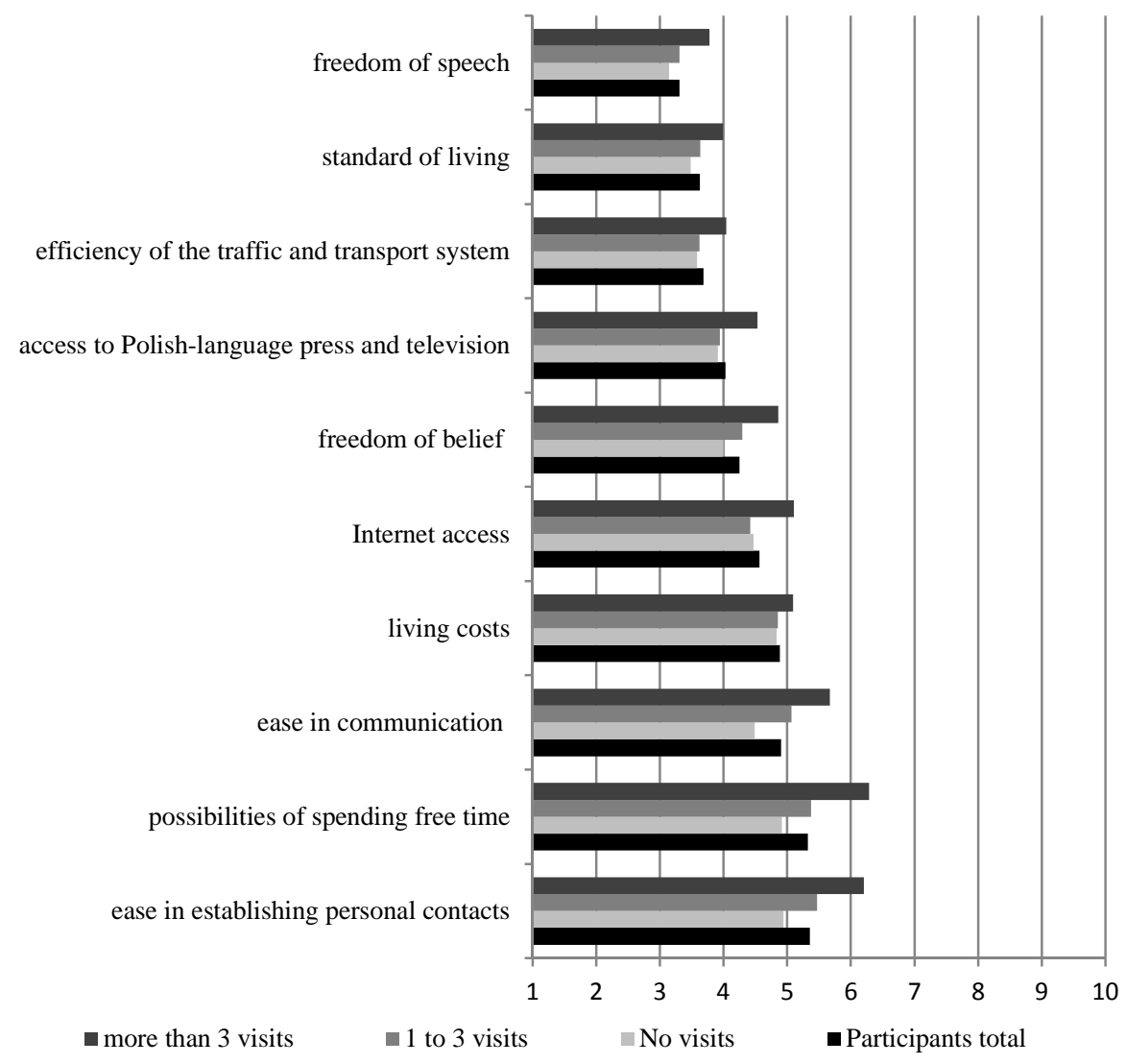

Source: prepared by the author. 
It is worth mentioning that, in this case, the opinions of people who have never visited Ukraine, and those who have visited the country up to three times, are relatively comparable. Better ratings can be seen only among persons, who have visited this country more often. The presented situation most likely results from the fact that, on the one hand, the question within this area related to work environment, while on the other hand, as it was previously mentioned, from among the people from the second group (1 to 3 trips), most of the visits have been of a tourist or training nature, therefore, these persons could not have the occasion to learn the specific character of the raised issues.

The last analysed area on the perception of the Ukrainian market included its sociopersonal aspects (graph 3). Firstly, it should be noted here that the perception of the subsequent analysed issues was significantly better than previously, although it was still quite negative. The highest rating in this case was obtained by ease in establishing contacts, for which the average rating calculated for the whole examined sample reached the value of 5.35. The respondents gave a slightly lower rating to possibilities of spending free time (4.90) and living costs (4.88). The lowest ratings were given to freedom of speech (3.31), standard of living (3.63) and efficiency of communication (3.69).

As previously, discrepancies in opinions can be also seen of the surveyed persons, who have never visited Ukraine, and of those, who have visited the country at least once. Statistically significant differences were observed in all of the examined aspects, except for living costs $(\mathrm{p}=0.35)$. At the same time, it should be noted that:

[1] In the case of freedom of speech, standard of living, efficiency of communication, access to Polish-language press and television, as well as Internet access, the observable differences correspond to the respondents, who have visited the country in question at least four times. The respondents, who have visited Ukraine up to three times, assessed the mentioned aspects similarly to those, who have never visited this country;

[2] In the case of freedom of belief, ease in communication, possibilities of spending free time, as well as ease in establishing contacts, the ratings get systematically higher along with the increase in the number of times the surveyed persons have visited Ukraine.

\section{SUMMARY}

The conducted survey validates drawing a number of conclusions with regard to the way Polish employees perceive the Ukrainian labour market. The first issue that can be observed is that this market is perceived in a clearly negative way. This fact is proved by both the previously presented evaluation of the results of the particular analysed issues, as well as the comprehensive assessment of its attractiveness - the average value of answers to the question given to the respondents concerning a general attractiveness assessment of the Ukrainian labour market amounted only to 3.70 on a ten-grade scale of measurement.

Nonetheless, it should be noted that this strongly negative assessment seems to be, at least to some extent, a derivative of the stereotype prevalent among Poles. The first thing that may prove its existence is the positive shift in the opinion about the Ukrainian labour market, which appears along with the increase in the number of visits to Ukraine, noticeable both in a considerable part of the analysed detailed issues, as well as in the case of a general attractiveness assessment. The average general rating given by people, who have visited this country at least once, but less than four times, was 3.81, whereas the rating given by people, who have visited at least four times, reached the value of 4.25. 
On the basis of the previous discussion, the areas subject to analysis of the way the Ukrainian labour market is perceived can be divided into three categories:

[1] Not related to the functioning stereotypes, or related to very strong stereotypes, difficult to challenge even during a personal stay. These may include any variables, in the case of which there was no difference in assessment between people which have not visited Ukraine, and those, who have visited Ukraine, namely: observance of law and order, quality of the public administration's operation and living costs.

[2] Potentially related to a functioning stereotype, the verification of which takes place during a visit to the discussed country. This group includes all variables, in the case of which the ratings given by persons, who have visited Ukraine are clearly higher than those given by persons, who have never been there. These include particularly attitude of community towards foreigners, ease in establishing contacts, ease in communication, access to information, situation of the economy, freedom of belief and possibilities of spending free time.

[3] Potentially related to a functioning stereotype, the verification of which requires a stay related to a deeper contact with the labour market or the business environment. This group includes the majority of variables from the group of professional aspects, in particular atmosphere in the work environment, but also Internet access and access to Polish-language press and television.

Secondly, it is worth emphasizing that, although it can be presumed that a set of stereotypes functions to some extent, they do not correspond in any way to the clearly negative receipt of the discussed market. The positive shift in the opinion about the Ukrainian labour market among people having experiences with the Ukraine is not significant and does not validate putting forward a thesis that the perception of the surveyed persons is highly inconsistent with reality. An exception to this conclusion seems to include the variables related to interpersonal contacts (attitude towards foreigners, ease in establishing contacts, ease in communication) - in their case, we can even refer to positive opinions, especially among people visiting the examined country often, as well as to a large dissonance in assessments between these people and the respondents who have never been to Ukraine.

Finally, it should be noted, that the empirical data had been gathered before the unrests that took place in 2014. Nonetheless, that fact most probably does not impair their validity. Obviously the market is perceived in such a negative way that the recent events are unlikely to make employee opinions visibly worse.

\section{LITERATURE}

[1] Adamiak J., Chendoszko R., Golec A., Jarecka J., Jastrzębska D., Lechowska P., Nowak A., Startek M., Wojciechowska K., Wybrane aspekty regulacji podatkowych we wskazanych krajach Europy jako potencjalny czynnik wptywajacy na emigracje, ,Zeszyty Naukowe Uniwersytetu Szczecińskiego” 818, „Finanse, Rynki Finansowe, Ubezpieczenia” 2014/68.

[2] Churchill G.A., Badania marketingowe. Podstawy metodologiczne. Wydawnictwo Naukowe PWN, Warszawa 2002.

[3] Czarnecki A., Atrakcyjność rynków pracy matych miast w Polsce (dla ludności miejscowej $i$ dojeżdżających), „Studia Ekonomiczne/Uniwersytet Ekonomiczny w Katowicach” 144/1 (2014).

[4] Finckenauer J., Shrock J., The Prediction and Control of Organized Crime: The Experience of Post-Soviet Ukraine, Transaction Publishers, Edison, New Jersey 2003. 
[5] Firlit-Fesnak, G., Polityka spoteczna w Polsce wobec wspótczesnych procesów migracyjnych. Próba diagnozy i rekomendacje, "Studia Migracyjne - Przegląd Polonijny" 39/149 (2013).

[6] Iglicka K., Gmaj K., Circular Migration Patterns between Ukraine and Poland, [in:] Triandafyllidou A., Circular Migration Between Europe and Its Neighbourhood: Choice Or Necessity?, Oxford University Press, Oxford 2013.

[7] Informacja o rozmiarach i kierunkach emigracji z Polski w latach 2004-2013, GUS, Warszawa 2014.

[8] Hanson M., Transition in Ukraine, Report Number 065 Escew 06 E, NATO Parliamentary Assembly, Brussels 2006.

[9] Machtakova O., Employee motivation in Ukrainian enterprises, "Вісник соціальноекономічних досліджень” 3/46 (2012).

[10] Massey D.S., Arango J., Hugo G., Kouaouci A., Pellegrino A., Worlds in Motion: Understanding International Migration at the End of the Millennium, Oxford University Press, Oxford 1999.

[11] Pasternak-Malicka, M., Przyczyny i skutki migracji zagranicznych młodych Polaków, „Zeszyty Naukowe Uniwersytetu Szczecińskiego” 787, „Współczesne Problemy Ekonomiczne. Globalizacja. Liberalizacja. Etyka" 2013/7.

[12] Rodgers P., Williams C., Round J., Workplace crime and the informal economy in Ukraine: Employee and employer perspectives, "International Journal of Social Economics" 35/9 (2008).

[13] Verkhohlyad O., McLean G.N., Applying organizational commitment and human capital theories to emigration research, "European Journal of Training and Development" 36/2-3 (2012).

\section{UKRAIŃSKI RYNEK PRACY W OPINII POLAKÓW - STEREOTYPY CZY NEGATYWNE DOŚWIADCZENIA?}

Na przestrzeni ostatniego dziesięciolecia krótko- i długoterminowa emigracja zarobkowa stała się typowym i nieodłącznym elementem polskiego rynku pracy. Do najczęściej wybieranych kierunków wyjazdów można zaliczyć w większości wypadków państwa Europy Zachodniej, Norwegię, coraz rzadziej natomiast Stany Zjednoczone. Co ważne, celem wyjazdu prawie nigdy nie są wschodni sąsiedzi Polski. Pojawić się może zatem pytanie o przyczyny wspomnianej niechęci do podejmowania pracy w tej części kontynentu. Czy powodowana jest ona wyłącznie czynnikami natury ekonomicznej, czy źródło leży także w obszarze zwykle dość negatywnego wizerunku krajów wschodniej Europy. Celem niniejszego artykułu jest próba oceny, na przykładzie rynku ukraińskiego, postrzegania przez polskich pracowników wschodnich rynków pracy. Ponadto zweryfikowano, do jakiego stopnia oceny te są pochodną funkcjonujących stereotypów czy konsekwencją własnych doświadczeń zawodowych. W trakcie prowadzonych badań liczna grupa respondentów (3129 osób) została poproszona o ocenę ukraińskiego rynku pracy w aspekcie jego aspektów wizerunkowych i kulturowych, społecznych i osobistych, jak również oferowanych perspektyw zawodowych. Pozyskany materiał badawczy jednoznacznie i wyraźnie ujawnił niezwykle negatywny obraz badanego rynku w opinii polskich pracowników. Najgorzej postrzegane były zmienne związane z oferowanymi warunkami pracy i zatrudnienia, najlepiej - chociaż nadal względnie negatywnie - te dotyczące społeczeństwa, w szczególności zaś relacji interpersonalnych. Równocześnie należy podkreślić, że można mówić o funkcjonujących stereotypach - wizyta na Ukrainie w pewnym stopniu skutkuje poprawą opinii na temat tamtejszego rynku pracy.

Słowa kluczowe: Ukraina, rynek pracy, opinie polskich pracowników

\section{DOI: 10.7862/rz.2015.mmr.8}

Tekst złożono w redakcji: marzec 2015

Przyjęto do druku: marzec 2015 